\title{
Potential of Ornamental Stony Corals in Kendari Waters, South- east Sulawesi
}

\author{
Rikoh Manogar Siringoringo ${ }^{1 *}$, Ni Wayan Purnama Sari ${ }^{1}$, MuhammadAbrar ${ }^{1}$, Risandi Dwirama Putra ${ }^{2}$, Ofri Johan ${ }^{3}$ \\ ${ }^{1}$ Research Centre for Oceanography - National Research and Innovation Agency, Indonesia \\ ${ }^{2}$ Naval Architecture Department, Faculty of Engineering, Universitas Maritim Raja Ali Haji, Indonesia \\ ${ }^{3}$ Research Institute for Ornamental Fish Culture, Ministry of Marine Affairs and Fisheries, Indonesia
}

\begin{abstract}
The utilization of ornamental corals in Indonesia is quite high because Indonesia is the biggest coral exporting country in the world. The high level of ornamental coral uptake in the wild so far has been big attention to the government as the contribution at reducing coral population, worsen the status of coral that is already in $35 \%$ poor condition. The research to determine the status of wild ornamental corals in the waters of Kendari carried out at nine locations. It aimed at determining the existence of ornamental corals in nature along with habitat conditions through the composition and diversity of ornamental coral parameters. The results showed the potential use of ornamental corals grouped by genera, namely as many as two genera (Porites and Fungia) included in the common group, as many as eight genera in uncommon, 18 genera in rare, and 31 genera in very rare. The location of habitat has live coral cover from $8.67 \%-55.17 \%$ including very poor to the good condition because some locations found high rubble and sand. Based on calculations, corals that can be utilized are grouped in the common category (genera Fungia and Porites), while the genera Acropora, Montipora, Pavona, Pectinia, Euphyllia, Favia, Galaxea, Seriatopora belong to the uncommon group, which means limited use. Rare groups are very limited in their use and very rare are prohibited from being used.
\end{abstract}

Key Words: Potential uses; Ornamental corals; Kendari

\section{Introduction}

The waters of Kendari is a domain of the world's coral triangle or better known as the area of CTI (Coral Triangle Initiative) which has a very high coral diversity. According to [1] coral diversity could reach up to 590 species in the Waters of Indonesia, especially within the eastern parts of Indonesia. The number of coral species living in the Indonesian waters is reported to have more than 70 genera and 450 with more of the distribution concentration in Eastern Indonesia domain, such as Sulawesi, Maluku, and Nusa Tenggara [2;3]. The harvest of live corals takes place in 11 Province in Indonesia, one of them is Southeast Sulawesi [4].

In the domain of Kendari waters, Sulawesi Tenggara, the results of research which had been conducted by [5] recalls that the percentage of coral coverage could reach $60,25 \%$ or be categorized as "good". [6] also stated that the coral coverage condition in Hari Island and Saponda Island is still in a good condition namely within the range of $50 \%-75 \%$. The same applies to the surrounding small islands which also are in a good category. The coastal areas of the small islands have a very good potential for coral growth and fisheries since the waters are relatively immaculate and in some locations, the ecosystem of seagrasses, mangroves, and the ecosystem of coral reefs are encountered simultaneously. The condition therein pictures that the condition of coral reefs in this location is still sufficiently good hence could provide good benefits from an economic perspective or ecological perspective. Regardless the executions of full-scale management and preservation of corals are necessary for the maintenance of its balance [7].

One of the forms of coral usage is coral trades for ornamental coral demands in aquariums. Coral usage for trades is not excluded from the potential of corals available in nature. To regulate the trading activities hence the "Management Authority" party has issued policies which among them states that the taking of corals is not only concentrated on a certain location, instead, it concentrated on various different locations. This is conducted in order to not let the degradation occurs due to excessive coral takings. Then the monitoring and evaluation on taking locations need to

*Corresponding author: rikoh.manogar@gmail.com 
be done as well. The observation at this time are conducted to figure out the potencial of ornamental corals available in some of the observation location. The results of this observation are expected to be taken advantage of as a basis in determining policies in sustainable ornamental coral trades management.

\section{Materials and methods}

\subsection{Time and Location}

This research was conducted on Month of March 2012. The Location of the Research is divided into 9 sites around the Waters of Kendari, namely in Labuan Beropa, Toronipa, Bokori Is., Labutaone, Tanjung Gomo, Saponda, Tondogeu, Langara 1 and Langara 2. The full details of coral observation location can be seen on Figure 1 and the observation position can be seen on Table 1 .

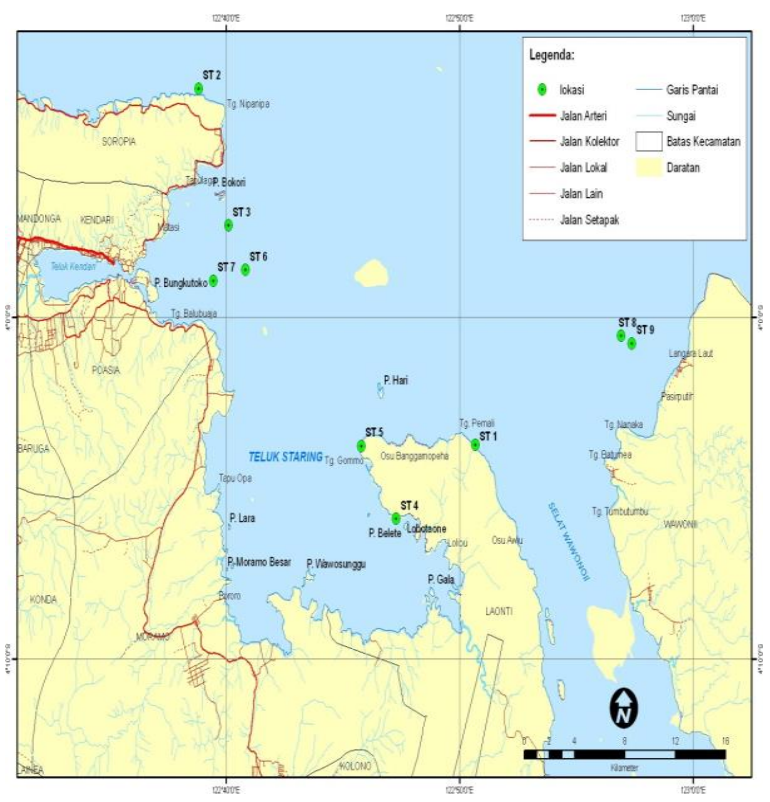

Fig. 1. Coral observation sites
Table 1. Geographic position of observation site in Kendari

\begin{tabular}{|c|c|c|c|}
\hline $\begin{array}{l}\text { Site } \\
\text { code }\end{array}$ & Sites name & Latitude & Longitude \\
\hline ST 1 & $\begin{array}{l}\text { Labuan Baropa, } \\
\text { Kec. Launti, Kab. } \\
\text { Konawe Selatan }\end{array}$ & $4.06219^{\circ}$ & $122.84469^{\circ}$ \\
\hline ST 2 & $\begin{array}{l}\text { Toronipa, Kec. } \\
\text { Soropia, Kab. } \\
\text { Konawe }\end{array}$ & $3.88873^{\circ}$ & $122.64702^{\circ}$ \\
\hline ST 3 & $\begin{array}{l}\text { P. Bokori, Kab. } \\
\text { Konawe }\end{array}$ & $3.9553^{\circ}$ & $122.66832^{\circ}$ \\
\hline ST 4 & $\begin{array}{l}\text { Labutaone, Kec. } \\
\text { Laonti, Kab. } \\
\text { Konawe Selatan }\end{array}$ & $4.0981^{\circ}$ & $122.78819^{\circ}$ \\
\hline ST 5 & $\begin{array}{l}\text { Tg. Gomo, Kec. } \\
\text { Laonti, Kab. } \\
\text { Konawe Selatan }\end{array}$ & $4.06263^{\circ}$ & $122.76318^{\circ}$ \\
\hline ST 6 & Saponda, Konawe & $3.97694^{\circ}$ & $122.68058^{\circ}$ \\
\hline ST 7 & $\begin{array}{l}\text { Tondogeu, } \\
\text { konawe }\end{array}$ & $3.98218^{\circ}$ & $122.65766^{\circ}$ \\
\hline ST 8 & $\begin{array}{l}\text { Langara 1, } \\
\text { Wowoni }\end{array}$ & $4.00906^{\circ}$ & $122.94869^{\circ}$ \\
\hline ST 9 & $\begin{array}{l}\text { Langara 2, } \\
\text { Wowoni }\end{array}$ & $4.01269^{\circ}$ & $122.95644^{\circ}$ \\
\hline
\end{tabular}

\subsection{Data Sampling Methods}

Sampling of coral data in the field is consisted of the form of coral growth, coral identification to species level, and density of stony corals. Visual observation on coral reefs habitat condition is also carried out as a whole whether from the view of undersea topography, bottom substrate, condition of waters, brightness or even observation on endemic or rare coral species. The observation is also completed with the documentation of corals by the use of underwater camera and the sampling of endemic and rare coral samples. In full detail the methods of coral reefs sampling are explained as follows:

\section{LIT (Line Intersept Transect) [8]}

This method is conducted by spreading transect line with length of $70 \mathrm{~m}$ adjacent to the coastal line in every station points. The measurement on coral growth form (life form) is conducted along the lengths of $10 \mathrm{~m}$, three times repetitions with the interval of $20 \mathrm{~m}$ between repetition transects. First transect is carried out on 0$10 \mathrm{~m}$, second transect on $30-40 \mathrm{~m}$, and third transect on $60-70 \mathrm{~m}$. All of the coral species and other benthic categories present underneath the transect line are logged with precision closing to centimeter. The coral species can have their totals and lengths calculated, then can have their diversity indices value calculated by the assistance of statistic program Primer 5. Then the coral species with unknown name have their samples and photos taken by the use of underwater camera for further identification by the use of books $[9 ; 10]$. 
2. Belt transect [11]

Sampling for coral density is carried out by the use of $2 \times 10 \mathrm{~m}$ quadrant transect which is installed along the transect line. The number of repetitions in one station point is 3 (Three). Data sampling is carried out by measuring and counting coral colonies within the area of the transect. Then the sizes of coral colonies are divided into 4 sizes namely $0-5 \mathrm{~cm}, 6-15 \mathrm{~cm}, 16-25$ $\mathrm{cm}$ and $>25 \mathrm{~cm}$. The grouping of these sizes is assumed to be the difference between grown adult corals and immature corals. Then however the definition of immature corals must be decided carefully. The importance this time is not to observe recruitment rather it's only to differentiate colony sizes to figure out the compositions of the coral sizes.

\subsection{Calculation Of Ornamental Corals Usage Recommendation}

Recommendation of ornamental corals usage is obtained by calculating some parameters to obtain Total Value (TV), which includes total of occurrence, relative frequency (RF), Dominant Frequency (DF), colony size (Size of Colony-SoC). Based on the data of the entire transect location, length of each genus can be calculated by the total of occurrences. Then the "Relative Frequency" (RF) can also be calculated : The total of occurrence from one genus from the total of occurrences of the entire genera. Then the "Relative Dominance" (RD) can also be calculated : coverage percentage from one genus to coral coverage of the entire genera [7].

Total of Occurrence of one genus

Relative Frequency:

Total of Occurrence of the entire coral genera

Relative Dominance (RD): Coral cover of one genus

Cover of the entire coral genera

Values for the Hard Coral (HC) percentage are divided into 4 categories, namely:

$-<25 \%, 25-<50 \%, 50-<75 \%$ and $75-100 \%$

Values submitted for SoC (Size of Colony) at this moment are the minimum score which is 1 , this is because generally the coral sizes are dominated by coral sizes of $<16 \mathrm{~cm}$. Next for the continuing observation it can be adjusted in accordance to its formula and needs.

Based on the approach of a formulation to calculate coral genera abundance [7], the interval for each category are presented on the Table 2 below.
Table 2. Interval for each category based on scale, weight, and value

\begin{tabular}{|c|c|c|c|c|}
\hline Category & Interval & Scale & Weight & Value \\
\hline SoC & $\begin{array}{c}\text { SoC } \leq 16.09 \\
\mathrm{~cm} \\
16.09 \mathrm{~cm}< \\
\text { SoC } \leq 21.73 \\
\mathrm{~cm} \\
21.73 \mathrm{~cm}< \\
\text { SoC } \leq 29.34 \\
\mathrm{~cm} \\
\text { SoC }>29.34 \\
\mathrm{~cm}\end{array}$ & $\begin{array}{l}1 \\
2 \\
3 \\
4\end{array}$ & $\begin{array}{l}1 \\
1 \\
1 \\
1\end{array}$ & $\begin{array}{l}1 \\
2 \\
3 \\
4\end{array}$ \\
\hline RF & $\begin{array}{c}\mathrm{RF} \leq 0.08 \% \\
0.08 \%<\mathrm{RF} \\
\leq 0.34 \% \\
0.34 \%<\mathrm{RF} \\
\leq 1.40 \% \\
\mathrm{RF}>1.40 \%\end{array}$ & $\begin{array}{l}1 \\
2 \\
3 \\
4\end{array}$ & $\begin{array}{l}2 \\
2 \\
2 \\
2\end{array}$ & $\begin{array}{l}2 \\
4 \\
6 \\
8\end{array}$ \\
\hline RD & $\begin{array}{c}\mathrm{RD} \leq 0.07 \% \\
0.07 \%<\mathrm{RD} \\
\leq 0.28 \% \\
0.28 \%<\mathrm{RD} \\
\leq 1.21 \% \\
\mathrm{RD}>1.21 \%\end{array}$ & $\begin{array}{l}1 \\
2 \\
3 \\
4\end{array}$ & $\begin{array}{l}1 \\
1 \\
1 \\
1\end{array}$ & $\begin{array}{l}1 \\
2 \\
3 \\
4\end{array}$ \\
\hline HC & $\begin{array}{c}\mathrm{HC} \leq 25 \% \\
25 \%<\mathrm{HC} \leq \\
50 \% \\
50 \%<\mathrm{HC} \leq \\
75 \% \\
\mathrm{HC}>75 \%\end{array}$ & $\begin{array}{l}1 \\
2 \\
3 \\
4\end{array}$ & $\begin{array}{l}1 \\
1 \\
1 \\
1\end{array}$ & $\begin{array}{l}1 \\
2 \\
3 \\
4\end{array}$ \\
\hline
\end{tabular}

Note: SoC : Size of Colony; RF : Relative

Frequency, RD : Relative Dominance; HC : Hard coral cover.

Based on the values from $\mathrm{SoC}, \mathrm{RF}, \mathrm{RD}$ and $\mathrm{HC}$ on each location hence the Total Value (TV) can be calculated by the following formula:

$\mathrm{TV}=\mathrm{SoC}+\mathrm{RF}+\mathrm{RD}+\mathrm{HC}$.

SoC : Size of Colony

RF : Relative Frequency

$\mathrm{RD}$ : Relative Dominance

$\mathrm{HC}:$ Hard coral cover

Recommendation or action which can be carried out by the decision maker based on the values from TV are presented in Table 3. 
Table 3. Criteria for decision makers

\begin{tabular}{|c|c|c|}
\hline $\begin{array}{l}\text { Interval } \\
\text { TV }\end{array}$ & Criteria & Recommendation/ action \\
\hline $17-20$ & Very common & Harvest allowed \\
$14-16$ & Common & Harvest allowed with \\
$11-13$ & Uncommon & caution \\
$8-10$ & Rare & Harvest limited \\
$5-7$ & Very rare & Harvest strictly limited \\
& & Harvest prohibited \\
\hline
\end{tabular}

Note: $\mathrm{TV}=$ Total value

\section{Results dnd Discussion}

\subsection{General condition of the coral reefs}

Some parts of the observation location are sandy beaches and have rough rocky areas and others are high elevation areas and hills. Reef flats are various from the short ones to moderate ones with relatively moderate to steep beach profile. Coral occurrences are found from the depths of $1-30 \mathrm{M}$, the deeper depths only have sandy flats. Condition of the waters' brightness levels generally start from relatively moderate to clear.

Observation results with method of LIT have obtained percentage of coral cover categorized as "moderate" [12] with average value of coral cover percentage of $32,80 \%$. Percentage of viable coral cover starts from 8,67\% - 55,17\%. The highest coral percentage is located in Station 3 ( Bokori Is.) whereas it's the lowest in Station 5 (Tanjung Gomo). In some locations, other than the high coral cover percentage, the complexity level of corals are also relatively high especially in Station 1, Station 2 and Station 3. The low coral coverage is marked by high numbers of coral rubble and sandy areas in some locations such as the one in Station 5 (Tanjung Gomo), where the numbers of coral rubble is the highest with the percentage of $33.83 \%$ and $41.83 \%$.

In spite of low coral cover percentage value, it's not necessarily followed by low diversity level. Cover percentage are NOT positively correlated with coral diversity. Values of cover percentage of viable corals in each location can be seen on full detail on Figure 2, and the cover Percentage and other benthic categories are presented in Table 4.

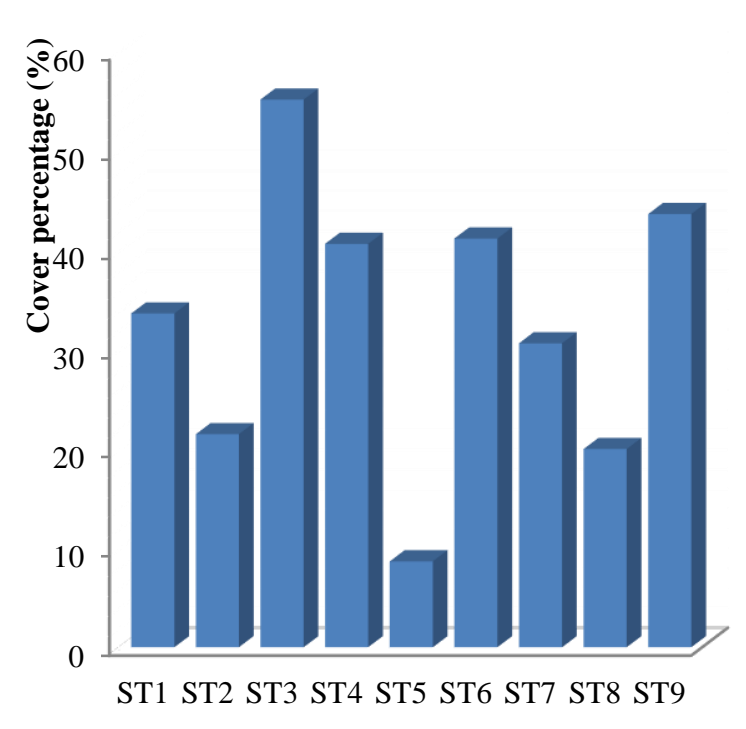

Sites location

Fig. 2. Viable coral cover percentage in each location (ST1: Labuan Baropa, Laonti Reg., ST2: Toronipa, Soropia Reg., ST3: Bokori Is., ST4: Labutaone, Laonti Reg., ST5: Tanjung Gomo, Laonti Reg., ST6: Saponda, Konawe, ST7: Tondogeu, Konawe, ST8: Langara 1, Wowoni, ST9: Langara 2, Wowoni).

Table 4. Cover percentage and other benthic categories (DC: Dead Coral, DCA: Dead Coral with Algae, MA: Macro Algae, CA: Coraline Algae, OT: Other fauna, R: rubble, S: Sand, SC: Soft Coral, SP: Sponge, TA: Turf Algae)

\begin{tabular}{|c|c|c|c|c|c|c|c|c|c|}
\hline \multirow{2}{*}{ BENTHIC } & ST & ST & ST & ST & ST & ST & ST & ST & ST \\
& 1 & 2 & 3 & 4 & 5 & 6 & 7 & 8 & 9 \\
\hline LIVE & 33. & 21. & 55. & 40. & 8.6 & 41. & 30. & 20. & 43. \\
CORAL & 67 & 50 & 17 & 67 & 7 & 20 & 67 & 00 & 67 \\
\hline \multirow{2}{*}{ DC } & 2.1 & 0.3 & 1.6 & 0.6 & 0.5 & 0.3 & 0.0 & 0.0 & 2.3 \\
& 7 & 3 & 7 & 7 & 0 & 3 & 0 & 0 & 3 \\
\hline \multirow{2}{*}{ DCA } & 15. & 39. & 26. & 50. & 13. & 21. & 23. & 20. & 20. \\
& 33 & 83 & 50 & 50 & 67 & 13 & 67 & 33 & 33 \\
\hline \multirow{2}{*}{ MA } & 0.6 & 0.3 & 1.1 & 5.0 & 0.0 & 4.8 & 0.0 & 0.0 & 0.0 \\
& 7 & 3 & 7 & 0 & 0 & 3 & 0 & 0 & 0 \\
\hline \multirow{2}{*}{$\mathrm{CA}$} & 0.0 & 0.0 & 0.0 & 0.0 & 0.0 & 0.0 & 0.0 & 0.0 & 5.0 \\
& 0 & 0 & 0 & 0 & 0 & 0 & 0 & 0 & 0 \\
\hline \multirow{2}{*}{$\mathrm{OT}$} & 0.3 & 0.5 & 1.1 & 0.0 & 1.1 & 0.5 & 0.0 & 0.6 & 0.3 \\
& 3 & 0 & 7 & 0 & 7 & 0 & 0 & 7 & 3 \\
\hline \multirow{2}{*}{$\mathrm{R}$} & 25. & 11. & 3.1 & 0.0 & 33. & 6.0 & 11. & 2.0 & 8.3 \\
& 17 & 50 & 7 & 0 & 83 & 0 & 33 & 0 & 3 \\
\hline \multirow{2}{*}{$\mathrm{S}$} & 21. & 22. & 7.1 & 0.6 & 41. & 23. & 31. & 43. & 17. \\
& 67 & 67 & 7 & 7 & 83 & 50 & 00 & 83 & 33 \\
\hline \multirow{2}{*}{$\mathrm{SC}$} & 0.6 & 1.8 & 3.6 & 2.5 & 0.0 & 1.1 & 0.3 & 10. & 0.5 \\
& 7 & 3 & 7 & 0 & 0 & 7 & 3 & 17 & 0 \\
\hline \multirow{2}{*}{$\mathrm{SP}$} & 0.3 & 1.5 & 0.3 & 0.0 & 0.3 & 1.3 & 3.0 & 3.0 & 2.1 \\
& 3 & 0 & 3 & 0 & 3 & 3 & 0 & 0 & 7 \\
\hline
\end{tabular}




\subsection{Composition and diversity of coral species}

Stony corals found in each location are in form of small patches which are encountered from reef flats to deeper areas. In general the bottom of the waters is consisted of dense deposits. On the hard substrate other biota can be found growing in great abundance, such as sponges, soft corals, gorgonians, ascidians, molluscs and various corals with very fascinating colorations. Stony corals are generally dominated by growth form of encrusting from species of Montipora sp and Porites sp., whereas the growth form of branching is dominated by species of Anacropora, Acropora and Porites cylindrica. Growth form of laminar is dominated by Echinopora lamellosa, Merulina ampliata and Pavona sp. Growth form of massive is dominated by Porites sp, Goniopora sp, then from the family Faviidae and Mussiidae, whereas the growth form of mushroom is dominated by species of Fungia spp and Heliofugia actinifomis.

Based on the results of observation conducted in the Waters of Kendari by using transect lines, there are encounters with 189 species of stony corals, 59 genera which are included in 16 families. Numbers of the stony coral species in the highest level are encountered in ST. 1 (108 species), ST. 7 (92 species) and ST. 2 (91 species).

Based on the numbers of stony coral occurrences encountered in transect lines in all of the research locations, the highest diversity index value $\left(H^{\prime}=4,15\right)$ also with the highest evenness index value $\left(\mathrm{J}^{\prime}=0,92\right)$ is located in ST. 7 (Tondogeu, Konawe) (Table 5). This value indicated that apart from the stony corals in the station are relatively more diverse compared to the other research stations, even their species distribution is also even, or can be stated that, none of any of the stony coral species which has apparent dominance compared to the others. The low level of evenness in ST1 is caused by relatively high dominance from species of Fungia sp with value of $21.76 \%$.

Table 5. Number of species (S), evenness index (J') and Diversity Index (H')

\begin{tabular}{|c|c|c|c|}
\hline & $\mathrm{S}$ & $\mathrm{J}^{\prime}$ & $\mathrm{H}^{\prime}$ \\
\hline ST1 & 108 & 0.75 & 3.49 \\
\hline ST2 & 91 & 0.85 & 3.83 \\
\hline ST3 & 79 & 0.83 & 3.61 \\
\hline ST4 & 80 & 0.89 & 3.91 \\
\hline ST5 & 69 & 0.87 & 3.68 \\
\hline ST6 & 79 & 0.90 & 3.93 \\
\hline ST7 & 92 & 0.92 & 4.15 \\
\hline ST8 & 44 & 0.87 & 3.30 \\
\hline ST9 & 85 & 0.88 & 3.91 \\
\hline
\end{tabular}

In general, the diversity level of stony corals in the Waters of Kendari has an apparent high level. This becomes an indication that the condition of the environment in the waters is still good, hence it could support lives of marine biota with the stony corals as one of them. Other than the high diversity level in this waters there are also encounters with species of high economic values which are rarely encountered in other locations.

Calculation results of coral colony abundance in each transect location are presented in Table 6. Coral abundance is calculated within the genera level. The genera consist of some species and their numbers have already been accumulated. Next the numbers of each genera in each location can be seen in Table 6 .

Table 6. Numbers of genus, numbers of individual and coral abundance in each location

\begin{tabular}{|c|c|c|c|c|c|c|c|c|c|c|}
\hline & $\begin{array}{c}\text { ST. } \\
1\end{array}$ & $\begin{array}{c}\text { ST. } \\
2\end{array}$ & $\begin{array}{c}\text { ST. } \\
3\end{array}$ & $\begin{array}{l}\text { ST. } \\
4\end{array}$ & $\begin{array}{c}\text { ST. } \\
5\end{array}$ & $\begin{array}{c}\text { ST. } \\
6\end{array}$ & $\begin{array}{c}\text { ST. } \\
7\end{array}$ & $\begin{array}{c}\text { ST. } \\
8\end{array}$ & $\begin{array}{c}\text { ST. } \\
9\end{array}$ & $\begin{array}{c}\text { Aver } \\
\text { age }\end{array}$ \\
\hline $\begin{array}{l}\text { Numbers of } \\
\text { genus }\end{array}$ & 49 & 44 & 40 & 37 & $\begin{array}{l}3 \\
8\end{array}$ & $\begin{array}{l}4 \\
0\end{array}$ & $\begin{array}{l}4 \\
0\end{array}$ & $\begin{array}{l}2 \\
9\end{array}$ & $\begin{array}{l}3 \\
5\end{array}$ & 39 \\
\hline $\begin{array}{l}\text { Numbers of } \\
\text { Individual }\end{array}$ & $\begin{array}{l}11 \\
44\end{array}$ & $\begin{array}{c}61 \\
3\end{array}$ & $\begin{array}{c}79 \\
7\end{array}$ & $\begin{array}{c}69 \\
5\end{array}$ & $\begin{array}{l}3 \\
9 \\
1\end{array}$ & $\begin{array}{l}4 \\
1 \\
7\end{array}$ & $\begin{array}{l}4 \\
2 \\
0\end{array}$ & $\begin{array}{l}1 \\
5 \\
9\end{array}$ & $\begin{array}{l}4 \\
0 \\
8\end{array}$ & 560 \\
\hline Abundance & $\begin{array}{l}19 . \\
07\end{array}$ & $\begin{array}{l}10 . \\
22\end{array}$ & $\begin{array}{l}13 . \\
28\end{array}$ & $\begin{array}{l}11 . \\
58\end{array}$ & $\begin{array}{l}6 . \\
5 \\
2 \\
\end{array}$ & $\begin{array}{l}6 . \\
9 \\
5\end{array}$ & $\begin{array}{l}7 . \\
0 \\
0\end{array}$ & $\begin{array}{c}2 . \\
6 \\
5\end{array}$ & $\begin{array}{l}6 . \\
8 \\
0\end{array}$ & $\begin{array}{c}9.3 \\
4\end{array}$ \\
\hline
\end{tabular}

By using the relative frequency, relative dominance, size of coral colony and coral cover percentage, corals within the genera level can be represented. Fungia and Porites are included in the "common" category because they have total values between 14 - 16, Acropora, Euphyllia, Favia, Galaxea, Montipora, Pavona, Pectinia and Seriatopora are in "uncommon" category with the Total Value between 11 - 13. In full details the abundance of coral genera in the entire location are presented in Table 7. 
Table 7. Coral genera abundance in Kendari Waters

\begin{tabular}{|c|c|c|c|c|c|c|}
\hline Genus & TV & Criteria & 31 & Lobophyllia & 8 & very rare \\
\hline Acanthastrea & 6 & very rare & 32 & Merulina & 8 & very rare \\
\hline Acropora & 11 & uncommon & 33 & Millepora & 8 & very rare \\
\hline Astreopora & 8 & rare & 34 & Montastrea & 6 & rare \\
\hline Barabatoia & 6 & very rare & 35 & Montipora & 11 & uncommon \\
\hline Blastomusa & 6 & very rare & 36 & Mycedium & 6 & very rare \\
\hline Caulastrea & 6 & very rare & 37 & Oulophylla & 6 & very rare \\
\hline Ctenactis & 6 & very rare & 38 & Oxypora & 8 & rare \\
\hline Cynarina & 6 & very rare & 39 & Pachyseris & 8 & rare \\
\hline Cyphastrea & 8 & rare & 40 & Paraclavarina & 6 & very rare \\
\hline Diaseris & 6 & very rare & 41 & Pavona & 11 & uncommon \\
\hline Diploastrea & 6 & very rare & 42 & Pectinia & 11 & uncommon \\
\hline $\begin{array}{l}\text { Echinophylli } \\
a\end{array}$ & 8 & rare & 43 & Physogyra & 6 & very rare \\
\hline $\begin{array}{l}\text { Echinophylli } \\
a\end{array}$ & 6 & very rare & 44 & Platygyra & 8 & rare \\
\hline Echinopora & 8 & rare & 45 & Plerogyra & 8 & rare \\
\hline Euphyllia & 11 & uncommon & 46 & Plesiastrea & 6 & very rare \\
\hline Favia & 11 & uncommon & 47 & Pocillopora & 8 & rare \\
\hline Favites & 8 & rare & 48 & Podabacia & 6 & very rare \\
\hline Fungia & 14 & Common & 49 & Polyphyllia & 6 & very rare \\
\hline Galaxea & 11 & uncommon & 50 & Porites & 14 & Common \\
\hline Gardinoseris & 6 & very rare & 51 & Psammocora & 6 & very rare \\
\hline Goniastrea & 8 & rare & 52 & Sandalolitha & 6 & very rare \\
\hline Goniopora & 8 & rare & 53 & Scolymia & 6 & very rare \\
\hline Halomitra & 6 & very rare & 54 & Seriatopora & 11 & uncommon \\
\hline Heliofungia & 8 & rare & 55 & Stylocoeniela & 6 & very rare \\
\hline Herpolita & 6 & rare & 56 & Stylopora & 6 & very rare \\
\hline Hydnopora & 8 & very rare & 57 & Symphyllia & 6 & very rare \\
\hline Leptastrea & 8 & very rare & 58 & Tubastrea & 6 & very rare \\
\hline Leptoria & 6 & rare & 59 & Turbinaria & 8 & rare \\
\hline Leptoseris & 8 & very rare & & & & \\
\hline Lithophylon & 6 & rare & & & & \\
\hline
\end{tabular}

Henceforth corals which can be used as ornamental corals with full caution from the 9 observation locations are only of the genera Fungia and Porites in common category, meanwhile other species Acropora, Montipora, Pavona, Pectinia, Euphyllia, Favia, Galaxea, Seriatopora are all included in the uncommon category, which implies restrictions in their usage. The rare category is very restricted in their usage and very rare ones are prohibited for usage [7].

The harvest/taking location of trade target corals or these research location only discovered fast growing corals [13] in small numbers, including the ones in uncommon category. The species include Acropora, Montipora, and Seriatopora. Meanwhile the trade target corals can be found from species of Heliofungia with rare status, to other species of Scolymia, Cynarina, Blastomusa, Lobophyllia, Physogyra, with their occurrence status being in very rare category. The location of target corals are not within one location, it's often found that there are findings of specific coral species per location in accordance to the habitat character such as being sandy, have currents, or coral stones [14].

Counting stocks in nature is one of the important aspects in deciding the coral quota. Formula for calculating coral abundance within genera level could represent coral abundance in general, even so there are assessments which are still need to be done within indepth level in order to obtain more perfect results. Then it is advised that monitoring of coral harvesting location needs to be carried out in order to constantly follow on its development whether there is a positive impact or a negative impact.

\section{Conclusion}

Corals with full caution from the 9 observation locations are only of the genera Fungia and Porites in common category meanwhile other species Acropora, Montipora, Pavona, Pectinia, Euphyllia, Favia, Galaxea, Seriatopora are all included in the uncommon category, which implies restrictions in their usage. Meanwhile the trade target corals can be found from species of Heliofungia with rare status, to other species of Scolymia, Cynarina, Blastomusa, Lobophyllia, Physogyra, with their occurrence status being in very rare category. The location of target corals are not within one location, it's often found that there are findings of specific coral species per location in accordance to the habitat character such as being sandy, have currents, or coral stones. Formula for calculating coral abundance within genera level could represent coral abundance in general, even so there are assessments which are still need to be done within indepth level in order to obtain more perfect results.

\section{References}

[1] Veron JEN. Corals of the world. Australian Institute of Marine Science, PMB3, Townsville MC, Qld4810, Australia Vol.2: 429 pp. (2000).

[2] Reksodihardjo G, Liliey. Buku Panduan Penggunaan Flipchart Terumbu Karang Indonesia. Jakarta : Direktorat Jendral Perlindungan dan Konservasi alam. USAID. Yayasan Pusaka Alam Nusantara. The Nature Conservation. Natural Resources Mangement Program (1999). 
[3] Veron, J.E.N., Devantier, L.M., Turak, E., Green, A.L., Kininmonth, S., Stafford-Smith, M. \& Peterson, N. Delineating the Coral Triangle. Galaxea, J. Coral Reef Studies, 11(2): 91-100. doi: 10.3755/galaxea.11.91. (2009).

[4] UNEP - WCMC. Review of selected corals from Indonesia. UNEP - WCMC, Cambridge. (2015)

[5] Siringoringo, R.M., R.D. Palupi, T. A. Hadi Biodiversitas Karang batu (Scleractinia) di Perairan Kendari. Ilmu kelautan vol. 17 (1) 23 30. (2012).

[6] Pramudji. Monitoring kesehatan terumbu karang dan ekosistem terkait di Kota Kendari dan sekitarnya (Jakarta: COREMAP-CTI) p 78 (2015).

[7] Suharsono \& Giyanto. A formulation Approach to Quantify the Abudance of Coral Genera. Mar. Res. Indonesia. 31: 1 - 11 (2006).

[8] English, S.; C. Wilkinson and V. Baker. Survey Manual for Tropical Marine Resources. Second edition. Australian Institute of Marine Science. Townsville : 390 pp. (1997)

[9] Veron JEN and M. Pichon. Scleractinia of Eastern Australia. Australian Institute of Marine Science. Monograph Series Vol.1: 86 pp. (1976).

[10] Veron JEN. Corals of the world. Australian Institute of Marine Science, PMB3, Townsville MC, Qld4810, Australia Vol.1: 463 pp. (2000).

[11] Mapstone, B.D. and Ayling, A.M. An investigation of optimum methods and unit sizes for the visual estimation of abundances of some coral reef organisms. Great Barrier Reef Marine Park Authority Research Publication No. 47, Townsville, 70 pp. (1998)

[12] Gomez, E.D. and Yap P H.Y. Monitoring Reef Condition. In : Kenchington R.A, Hudson BET, editor. Coral Reef Management handbook. Jakarta: UNESCO Regional office science and technology for Southeast Asia. Pp187 - 195. (1988).

[13] Giyanto. Perdagangan karang hias: suatu ancaman terhadap ekosistem terumbu karang. Oseana. 32(4):21-27. (2007).

[14] Johan, O., Budianto, A., Priono, B. Studi tentang hubungan antara jenis-jenis karang hias dengan karakterisasi habitat di beberapa lokasi di Indonesia. Prosiding Seminar Nasional Kelautan III, Universitas Hang Tuah, Surabaya. 37-42 p. (2007). 